\title{
Defence work sheds light on hospital bacteria
}

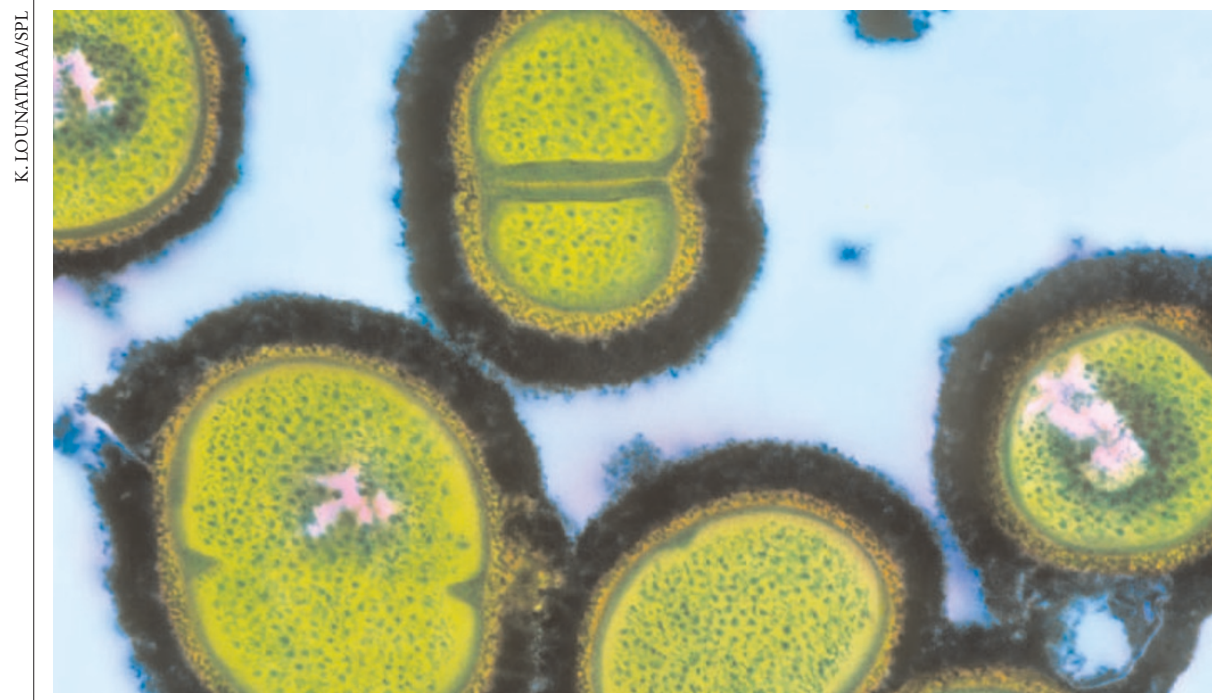

A light-sensitive method allows rapid detection of deadly methicillin-resistant Staphylococcus aureus.

Laura Nelson, London

Researchers have developed a test that will speed up the identification of antibioticresistant bacteria in hospitals, allowing quicker treatment for patients and curbing the spread of infections.

The test tracks down methicillin-resistant Staphylococcus aureus (MRSA) bacteria by tagging them with luminescent enzymes and measuring the light they give off. It uses technology first developed at the UK Ministry of Defence bioweapons laboratory at Porton Down in Wiltshire to monitor airborne bacteria for bioweapon detection.
"We have cut down the time needed for the diagnosis of MRSA," says Bill Mullen, chief executive of Acolyte Biomedica, a company based at Porton Down science park that has patented the test. Acolyte Biomedica has a licence agreement that gives it access to the defence lab's work.

Worldwide infections of MRSA have steadily escalated since it was first detected in the 1960s. In Britain, where the problem has caused widespread public alarm, MRSA costs the National Health Service $\mathfrak{£} 1$ billion (US\$1.8 billion) each year, according to the National Audit Office, which audits the accounts of government departments and agencies.

MRSA is usually carried asymptomatically on the skin, but causes infection when it enters wounds or affects weak immune systems. It can be fatal because its resistance to antibiotics makes it difficult to treat.

In the test, samples are taken from patients' nasal fluids and the swabs placed in liquid containing magnetic beads coated in antibodies that stick to the bacteria. These are then removed from the liquid using another magnet.

If MRSA cells are present in the sample, the beads will then be covered in them. To test this, the liquid coating the beads is placed in a dish with the antibiotic methicillin. This kills all other bacteria, leaving only the MRSA to divide and multiply.

After a few hours, the firefly enzyme luciferase, which reacts with adenosine triphosphate (ATP) in living cells to produce light, is added to the mix. The culture will glow if MRSA is present. Another compound, adenosine diphosphate, which amplifies the amount of ATP produced, is also added, increasing the test's sensitivity 100 -fold. Other tests for MRSA take days, rather than hours.

Mullen is pleased the military work will help to address a public-health problem. "We are turning swords into ploughshares," he says. He adds that the test will be tried out in hospitals from May and will be available for general use by early next year.

\section{Letters to the Editor deliver fitting April message}

\section{Alison Abbott, Munich}

Long ago, the residents of the Polish village of Chelm reputedly decided that the Moon was more important than the Sun, because it provided light when it was really needed at night.

This outlook apparently rules the roost at the Chelm Institute in Orange County, California. Each year, the Journal of Biological Rhythms, a circadian-biology journal, publishes unusual letters from the institute's researchers in its April issue.

Last year, for example, Nikolai Ivanovich Lobachevsky wrote in from the institute complaining of the "sappy sermons you call editorials", and giving readers advice on how to exploit the peer-review system to see off their competitors. In a previous year, the Chelm institute's more idealistic M. Pupique argued for a lottery system for selecting papers for publication or making academic appointments, to overthrow what he termed the "hegemony of the academic ruling class".

But the journal's editor Martin Zatz, a circadian biologist at the National Institutes of Health in Bethesda, Maryland, has now come clean and revealed that he writes the letters himself. They are April Fool's Day spoofs, intended to stimulate thoughts on important issues in science that Zatz considers worthy of a wider airing.

"I want to make the journal more interesting," he explains, "and some of the issues that interest me relate more to the human-nature side of science issues that are difficult to address in editorials."

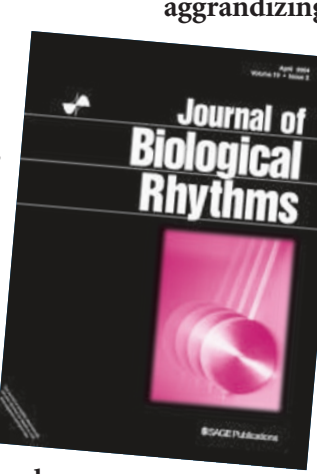

The letters attributed to Lobachevsky and Pupique allow Zatz to address concerns about the imperfections of peer review and proposed alternatives to it, Zatz says.

In this month's spoof, Quincy Adams Wagstaff, director of the Chelm Institute Omega Multi-Center Institute for
Co-operative Research in the 21st Century, boasts of his alleged discovery of the "Mother of all Clock Genes". Wagstaff's selfaggrandizing text praises the teamwork that led to the discovery - but it soon becomes apparent that the bombastic director has no intention of rewarding the rest of the team with either co-authorship or a share in a pending patent.

Some of the references in the spoof letters may pass many readers by. Not everyone, for example, will recall that Lobachevsky was a nineteenthcentury Russian mathematician, whose name was appropriated by Tom Lehrer in a 1960s song about plagiarism, or that Wagstaff was an anarchic college president in the Marx brothers' film Horse Feathers. Zatz is bemused by such shortcomings. "Few understand irony any more," he complains. 